\title{
DETERMINATION OF THE LEGAL STATUS FOR DISASTER EMERGENCY IN INDONESIA
}

\author{
Teuku Ahmad Dadek* \\ Husni Husni** \\ Mahdi Syahbandir*** \\ M. Ya'kub Aiyub Kadir**** \\ Yanis Rinaldi ${ }^{* * * *}$ \\ Sulaiman Sulaiman ${ }^{* * * * *}$
}

\begin{abstract}
Article 7 paragraph (2) of the Law Number 24 Year 2007 concerning Disaster Management (UUPB) stipulates that the establishment of a disaster emergency status must contain indicators that include the number of victims, property loss, the damage of the infrastructure and facilities, the extent to which an area is affected by the disaster and the socio-economic impacts that arise. Paragraph (3) of the article states that further provisions regarding the establishment of the status and the level of the disaster are regulated through a Presidential Regulation. However, the Presidential Regulation has not yet been issued while the Letter of Decision on the Disaster Emergency Status continues to be published, which causes legal uncertainty in its implementation. Hence this article investigates the legal mechanism in determining a disaster emergency status that guarantees legal certainty, its legal implications and steps the
\end{abstract}

* PhD student, Faculty of Law, Universitas Syiah Kuala (USK). Email: tdadek@gmail.com.

** Lecturer, Faculty of Law, Universitas Syiah Kuala (USK). Email: husnijalil@unsyiah.ac.id.

*** Lecturer, Faculty of Law, Universitas Syiah Kuala (USK). Email: msyahbandir@unsyiah.ac.id.

**** Lecturer, Faculty of Law, Universitas Syiah Kuala (USK). Email: m.yakub.akadir@unsyiah.ac.id.

*****Lecturer, Faculty of Law, Universitas Syiah Kuala (USK). Email: yanisrinaldi@unsyiah.ac.id.

******Lecturer, Faculty of Law, Universitas Syiah Kuala (USK). Email: sulaiman.fh@unsyiah.ac.id. 
(central) Government and the Regional Government should take in dealing with such legal implications. The research method employed in this study is the juridical normative research. Research on disaster legislation, especially in determining disaster emergency status, has not yet demonstrated legal certainty. This is due to the absence of legal mechanisms and positive legal formalities that are built from legal facts that lead to multiple interpretations and to legal disputes. The absence of the Presidential Regulation (Perpres) as a UUPB manifestation for determining emergency status of a disaster as stipulated by autonomous provinces/districts (Decree) has contributed to potential arbitrary use of state funds. Therefore, the Presidential regulation is urgently required.

Keyword: legal mechanisms during disasters, law in emergency situations, disaster management.

\title{
PENENTUAN STATUS DARURAT BAGI KECEMASAN BENCANA DI INDONESIA
}

\begin{abstract}
ABSTRAK
Artikel 7 perenggan (2) bagi Undang-undang Nombor 24 Tahun 2007 adalah berkenaan dengan Pengurusan Bencana (UUPB) menetapkan bahawa penetapan status kecemasan bencana mesti berdasarkan beberapa petunjuk. Anataranya ialah bilangan mangsa, kehilangan harta benda, kerosakan infrastruktur dan kemudahan serta sejauh mana sesuatu kawasan itu terkesan oleh bencana tersebut dan kesan sosioekonomi yang timbul. Perenggan (3) artikel tersebut menyatakan penetapan status tersebut dan tingkat becana yang di kawal selia oleh Peraturan Presiden. Walaubagaimanapun, tiada Peraturan Presiden yang telah dikeluarkan dan Surat Keputusan mengenai Kecemasan Bencana berterusan diterbitkan. Ini menyebabkan ketidakpastian undang-undang dalam pelaksanaannya. Oleh itu, makalah ini menyiasat mekanisme undang-undang bagi menentukan kecemasan bencana yang memastikan ketelusan undang-undang, implikasi undang-undang dan langkahlangkah yang perlu diambil oleh Kerajaan Pusat dan Pemerintahan Daerah dalam menangani implikasi undang-undang tersebut. Penyelidikan ini menggunakan kaedah penyelidikan normatif perundangan. Penyelidikan lampau yang mencakupi penentuan kecemasan bencana menunjukkan masih tiada kepastian undang-undang dalam menentukan status ini. Ini kerana tiada makanisme undangundang dan tiada formaliti undang-undang yang positif yang turut menyebabkan terdapat penilaian yang berbeza dan menyebabkan pertelingkahan undang-undang. Ianya juga menyebabkan penggunaan
\end{abstract}


dana negara secara sewenang-wenangnya. Oleh itu, terdapat keperluan yang mendesak kepada peraturan Presiden bagi mengatasi masalahmasalah ini.

Kata kunci: mekanisme perundangan dikala bencana, undangundang kecemasan dikala bencana, pengurursan bencana.

\section{INTRODUCTION}

The Law Number 24 of 2007 concerning Disaster Management (UUPB) requires that at least 6 (six) Government Regulations (PP) and 2 (two) Presidential Regulations (Perpres) should be issued. To date three Government Regulations have been issued which outline 6 (six) legal objects, which are referred to as the ones required by the UUPB. And, of the two requiring Presidential Regulations, one has not yet been issued, which relates to the establishment of a disaster emergency status. This Presidential Regulation is pivotal as it lays down the legal mechanism for determining a disaster emergency status of which indicators have been set by the UUPB. In its implementation, the regulation on determining the status and the level of severity of a disaster is still unclear and does not have a strong basis or mechanism according to legal perspectives.

In Indonesia, disaster management is divided into three stages; namely a) pre-disaster, b) emergency response, and c) post-disaster. UUPB still does not provide any distinction between disaster emergency status and disaster level. Disaster emergency phase is a very important period in protecting the lives of Indonesian people from the impact of disasters, especially in the evacuation activities, basic needs fulfilment, health care and others. A clear, fast, accurate and effective legal mechanism is required as much as that for legal certainty. According to Gustav Radbruch, legal certainty must fulfil four requirements. First, the law is positive or based on legislation. Second, the law is a fact, not a formulation of judgments made by judges, such as "good will" and "politeness". Third, that the facts must be clear, avoiding misinterpretations, as well as being easy to implement. Fourth, the positive law must not be changed frequently.

The establishment of an emergency status raises some unusual legal consequences, especially in the procurement of goods and services and the use of government funds at all levels. This is called 
accessibility which is the terminology stipulated in the UUPB. In the procurement of goods, for example, as the legal system requires that the procurement of goods above IDR 200 million must follow the bidding process, a regent's decree regarding the determination of the emergency status allows that a procurement of IDR 22 billion can be carried out without a bidding. Then, because there is no Presidential Regulation (Perpres) that regulates benchmarks, mechanisms and goals, the regional heads directly determine that a disaster can still be overcome without a strong study. Nevertheless, the disaster status is determined with the aim of getting financial assistance from Indonesian National Board for Disaster Management (BNPB).

The absence of a Presidential Regulation that provides legal mechanisms and the benchmarks for emergency status indicators raises several implications. The first legal problem is, it creates the absence of legal mechanisms on the issuance of a decree on the status and the level of a disaster. Second, the issuance of a decree on the status of a disaster provides the opportunities and potentials for various parties to arbitrarily use the funds. Third, the governments of different levels gain some bargaining powers throughout the process of establishing the status and the level of a disaster.

\section{PROBLEM IDENTIFICATION}

The formulation of the problem in this study concerns the legal mechanism for determining disaster emergency status that guarantee legal certainty, i.e., that do not cause multiple interpretations in applying the law and adhering to the material legal system.

\section{METHODOLOGY}

This study makes use of normative legal methods that put the law as a building system of norms consisting of the principles, norms, and rules of law. ${ }^{1}$ It traces the regulations and the literature related to the problems, ${ }^{2}$ such as the legislations, textbooks, journals, research

\footnotetext{
1 Mukti Fajar and Yulianto Achmad, Normative and Empirical Dualism of Legal Research (Yogyakarta: Pustaka Pelajar, 2010), 34.

2 Soerjono Soekanto \& Sri Mamudji, Normative Legal Research (A Short Review) (Jakarta: Rajawali Pers, 2001), 13-14.
} 
results, encyclopedia, cumulative indices, and etc. The research focuses on the norms and principles of positive law ${ }^{3}$ employing the legis positivis conception approach. This concept views the law as identical to written norms that are made and promulgated by an authorized institution or official. This concept also views law as a normative system that is independent, closed and detached from real community life. ${ }^{4}$

\section{DISCUSSION}

\section{Legal Status of Establishing a Disaster Emergency Status}

An emergency response constitutes the immediate responsive measures undertaken following a disaster in order to save lives, protect property and deal with direct damages caused by the disaster. ${ }^{5}$

The presence of a Presidential Regulation concerning the determination of an emergency status for the disaster is very important in several aspects. First, it serves as the basis for a legal mechanism, and at the same time it lays down the legal status through an issuance of a decree to establish the emergency status by the head of a state or region. UUPB states that the determination of disaster emergency status is commissioned by the government by considering the scale of a disaster. The determination of a disaster emergency status at the national scale is decided by the president; while at the provincial and the regency or municipality level is conducted by the governor and the regent or mayor, respectively (Article 51 paragraph (1) and (2). ${ }^{6}$

Second, the absence of scaling standard or the indicators on the magnitude of an occurrence - towards establishing the status whether it is a disaster or not - results in legal and political polemics, causing

3 Johnny Ibrahim, The Theory and Methodology of Normative Legal Research (Malang: Bayumedia Publishing, 2006), 295.

4 Ronny Hanitijo Soemitro, Legal Research and Jurimetry Methodology (Jakarta: Ghalia Indonesia, 1988), 13-14.

5 W. Nick Carter, Disaster Management: A Disaster Manager's Handbook (Philiphine: ADB, 2008), 230.

6 Op. cit, article. 51, paragraph. 2. 
the authorities in charge to lay the responsibility on another party as what happened following Lombok and Palu earthquakes. ${ }^{7}$

Third, it enables the emersion of miscellaneous legal perceptions on the handling of the emergency phase such as whether or not a permanent activity can be carried out during the disaster emergency phase, and how long the emergency phase is to adequately last in terms of certain time scale.

The head of the region continues to issue a Letter on Disaster Emergency Status Determination. It raises a question on how such an action can be performed in the absence of a legal mechanism. This is conducted on the basis of the delegation of authority as provided in the existing laws. A governmental authority has the right to carry out one or more management functions which include arrangements (regulation and standardization), management (administration) and surveillance (supervision) on a particular matter. ${ }^{8}$

In view of the regulation concerning the determination of an emergency status and the level of a disaster as mentioned in the existing UUPB and Government regulation (PP), in exemption of the required legislations, there are five conditions that must be met for establishing the emergency status of a disaster according to the UUPB:

First, there should be a series of legal mechanisms to be observed, namely the existence of rapid and accurate assessment on the damage and the availability of resources on the ground. This is aimed at ensuring whether or not the occurrence, according to the given legal definition, is categorised as a disaster.

Second, the status is determined through a decree issued by the central government (the president) and the regional government (the regent/mayor or the governor) to lay down a strong legal basis for initiating the emergency response activities under the fortification of certain legal exception or specificity, and it should also be terminated

7 Ramanditya Wimbardana and Saut Sagala "Setelah bencana Palu dan Lombok: sebuah babak baru tata kelola bencana di Indonesia?" The Conversation, accessed November 14, 2018, https://theconversation.com/setelah-bencana-palu-dan-lombok-sebuah babak-baru-tata-kelola-bencana-di-indonesia-106936.

8 Ganjong, Pemerintah Daerah Kajian Politik dan Hukum (Bogor: Ghalia Indonesia, 2007), 93. 
through a decree of the head of state and region. Third, there should be a timeline for handling the emergency response activities as an accountability mechanism, so as not to allow the process to be protracted beyond the given emergency period of time.

The Presidential Decree No. 80 of 2003 Paragraph 5 Letter b.4.a states that goods and or services users can issue a letter of Work Start Instruction (SPMK) after obtaining an approval from the authority in charge of financial matters and under the presence of a natural disaster declaration issued by the Governor.

Fourth, the handling of the emergency period is only aimed at dealing with the emergency matters - and not for permanent activities. It only covers the rescue and evacuation of victims and property, fulfilment of basic needs, protection and management of refugees, and restoration of infrastructure and facilities, the notion of which is frequently misunderstood. The activities conducted during this period are only to restore the basic functionality of the infrastructure and facilities so that the people can use them again. For instance, the function of bridges damaged by disasters can be restored by building emergency bridges whose structure was made from coconut tree trunks, and while that of destroyed houses can be restored by building temporary shelters such as tents and barracks. ${ }^{9}$

Article 39 of the Government Regulation number 21 of 2008 confines the procurement of goods and services to activities that require specific responsibilities such as the searching and rescuing the disaster victims, providing emergency first-aid treatment, evacuating the disaster victims, distributing the needs for clean water and sanitation, food, clothing, health services, camps and temporary shelters. In contrast however, the Presidential Regulation number 59 paragraph (6) states that the handling of emergency situations can be carried out through the use of permanent construction; in that, the handover of the permanent work is conducted within the time of the emergency period. Even more, paragraph (7) of the regulation states that, "if the handling of an emergency situation can only be overcome

9 Government Regulation of the republic of Indonesia Number 59 of 2010 Concerning amendment to Government Regulation Number 29 of 2000 Concerning the Implementation of Construction Services. 
through a permanent construction, the completion of the work can exceed the timeline of the emergency period."

Fifth, a decision letter that determines the status of a disaster must contain parameters and indicators. ${ }^{10}$ Before the Regional Disaster Management Agency (BPBD) and BNPB provide advice to the head of the state and/or the head of the regional government, a Rapid Assessment Team should be deployed to the ground to make sure that the emergency status indicators are met. The determination of the level and the status of a disaster in national and regional scale should consider the following indicators, including: a) number of victims; b) loss of property; c) damage of infrastructure and facilities; d) coverage of the disaster affected area; and e) socio-economic impacts that might arise.

There are problems that might arise in an emergency response work, especially when the disaster covers a very large area and consumes a huge number of casualties and property such as in the cases of the Earthquake in Palu, the tsunami in Aceh, and several other disasters in other parts of Indonesia - where unexpected incidents might happen such as lootings, ${ }^{11}$ arsons and unorganized bodies evacuation. $^{12}$ Thus, the Decree on Disaster Emergency Status Determination should come together with a strict regulation on security control and evacuation process activities. The government is responsible to provide assistance, and prevent random people from taking benefits (looting) from the situation under the pretext of helping the victims. ${ }^{13}$

The status and the level of a disaster are two different matters. Status is always associated with emergency conditions that occur in an area. Such status comes in a series of levels of gradations, namely: normal or safe, alert, cautious and prepared. Therefore, the status highlighted here is not a disaster status; rather, the status of a disaster

10 Indonesia Constitution, article. 7, section. 2.

11 Dadek, T Ahmad, Tsunami of Benevolence, A Subdistrict Head's Experience During the Tsunami in Meulaboh, a Note on a Disaster Occurence Suspected as the "Doomsday," (Banda Aceh: Pena, 2017) 72.

12 Ibid., 74.

13 Abraham Utama, "Penjarahan pasca gempa dan tsunami, bagaimana penegakkan hukum di Palu?,” BBC Indonesia, accessed October 3, 2018, https://www.bbc.com/indonesia/indonesia-45721520. 
emergency. Such a notion is in line with Article 51 of the Law Number 24 of 2007.

The definition of disaster level refers to the intensity and magnitude of a disaster occurrence that affect a certain scale of administrative territory - whose disaster impact might range from district or municipality, provincial, and national levels.

The authority to issue a letter on the determination of a disaster status is more likely to be at the hand of the head of regional government in the district or municipality level because they are the closest to observe and the first to act in the efforts to deal with emergency matters; while, the governor and the president will issue subsequent or further letter of decision on the level of the disaster.

Throughout the history of Indonesia, prior to the issuance of UUPB, the Indonesian Government had issued two Presidential Regulations concerning the establishment of national disaster emergency status. The first Presidential Regulation was the one number 254 of 1966 concerning the occurrence of Mount Awu eruption in Tahuna Sangir Talaud, North Sulawesi District on August 12, 1966. The issuance of this Presidential Regulation was based on the fact that the regional government was lacking funds although they had collected donations from the community of the region. Enhancing the status of the disaster justified the central government to discharge additional funds to help handle the disaster impacts. Therefore, the natural disaster of Mount Awu eruption was declared an extraordinary one or a national disaster and the Central Government was then justified to use the national budget funds under the control of the Minister of Finance not only to deal with the activities during the emergency response period but also to support the works during the rehabilitation and reconstruction period. ${ }^{14}$

Likewise, the occurrence of the Aceh earthquake and tsunami on December 26, 2004 also called for the issuance of the Presidential Regulation Number 112 of 2004 concerning the Declaration of the Natural Disaster and Tsunami Earthquake in Nanggroe Aceh Darussalam Province and the Province of North Sumatra as a National Disaster and a National Mourning Day. In its consideration section, as

14 Presidential Decree No. 254 of 1966 concerning the Annual Disaster Eruption of Mount Awu in Sangir Talaud Regency / North Sulawesi. 
the regulation reads "to support the efforts to overcome and restore the disaster impacts, it is deemed necessary to declare the disaster a National Disaster and National Day of Mourning".

In 2016, BNPB released a book on the guidelines for determining a disaster emergency status. However, the book is not a legal product or a rule of law. In the meantime, the issuance of a decision letter on a disaster yields very strong legal consequences especially when it relates with the use of funds and facilities. It can also bring about legal implications such as the prevalence of arbitrariness in the use of state funds which is prone to violations of law. Such guidelines are not a legal norm, for the nature of law is normative and it should be produced by a community to establish legal regulations. ${ }^{15}$

Gustav Radbruch stated that there are three basic legal ideas that are also identical to the three legal objectives, namely, justice, benefit and legal certainty. Justice is the material value that a law should contain, while legal certainty is the presence of a legal mechanism or formal procedure. ${ }^{16}$ The principle of legal certainty requires the presence of a warranty that the law is carried out in an expeditious or appropriate manner. In other words, a law is not merely a moral demand, but it factually characterizes justice. To that extent, a law should bear the nature of fairness, be carried out according to certain mechanisms, and be able to run its functions.

A law that does not provide certainty and fairness is not only a bad law, rather, it cannot even be considered as a law. It is these two characteristics that form the definition of the law itself (den begriff des Rechts). ${ }^{17}$ Certainty is essentially the main objective of the law. If the law brings about no certainty, the law will lose its identity and meaning. Without its identity, the law can no longer serve as a guideline for behavioural code of conduct for anyone. Legal certainty is "sicherheit des Rechts selbst" - a certainty about the law itself. ${ }^{18}$

15 Bernard L. Tanya. Et.al. Legal Theory of Human Orderliness Strategy across Spaces and Generations (Yogyakarta: Genta Publishing, 2010) 125.

16 Op. Cit, 129.

17 Shidarta, The Morality of Legal Profession: A Thinking Framework Proposal (Bandung: PT Revika Aditama, 2006), 79-80.

18 Sudikno Mertokusumo, Perkembangan Teori Dalam Ilmu Hukum, (Jakarta: RajaGrafindo Persada, 2010), 24. 
Legal certainty is closely related to four things. First, the law is positive, meaning that it is legislated (gesetzliches Recht). Second, the law is based on facts (Tatsachen), not a formulation of judgment on attitudes such as "goodwill" and "politeness" which will be made by judges. Third, the fact should be formulated in a clear way so as to avoid mistakes in its interpretation and to simplify its implementation. Fourth, a positive law should not experience frequent changes. Thus, the mechanism provided in the book does not constitute a legal mechanism; rather, it is only a technical guideline that cannot serve as a legal basis for resolving a legal case in the event of a dispute. ${ }^{19}$

The absence of the Presidential Regulation leaves the district or municipality and the province in the void of legal reference as a guideline for them in determining a disaster emergency status. Therefore, the handbook released by the BNPB is a mere technical book. The mechanism arrangement it provides does not function as a legal product, because it is just a book. ${ }^{20}$

In addition to the book, the head of the region and the president have used the Regulation - released by the Head of the National Disaster Management Agency Number 14 of 2010 concerning Guidelines for Establishing a Disaster Emergency Response Commanding Post - as of their reference.

\section{The Legal Implication of Disaster Emergency Status Establishment}

What is the legal function of the letter of declaring a disaster status, regardless of who issues it? First, it is to legally validate that an occurrence is a disastrous happening. For an occurrence to be declared as a disaster, it requires a process of consultation and review; and, when the review convincingly perceives it a disaster, swift and immediate measures need to be taken. Legal deviations may be justified in order to deal with unusual conditions such as lessening bureaucratic procedures. This is deemed necessary in order to minimize casualties

19 Satjipto Rahardjo, Law in the World of Orderliness (Jakarta: UKI Press, 2006), 135-136.

20 BNPB (National Disaster Management Agency), Guidelines for the Establishment of a Disaster Emergency Status (Jakarta: BNPB, 2016), 11. 
and property loss and to immediately deal with the disastrous conditions within the emergency phase.

Second, the state is required to release a statement to declare the promulgation of a special law. The establishment of a disaster emergency status is a legal effort done outside the court. It grants a statutory authority onto the head of a state and a regional government to enforce special laws through a decree that makes a public declaration on disaster emergency management. The letter on the promulgation of a disaster emergency law serves as an essential tool to effectively function with the heads of the state and the regional government because the letter is a statutory order. Thus, the function of the disaster emergency decree is equivalent to a legal instruction.

Does the effort to establish the status of a disaster emergency correspond to the legal principle of lex specialis derogat lex generalis? Such principle outlines that a special rule overrides a general rule. There are several principles that should be observed in the principle of lex specialis derogat lex generalis. First, the provisions contained in the general legal rules remain valid, except for those specifically regulated in the special legal rules. Second, the level of the provisions contained in the lex specialis rule are legally equal to those of the lex generalis rules (both are equally seen as 'a law versus a law'). Third, the provisions of lex specialis rule should exist in the same legal environment (regime) as those of lex generalis rule.

The Book of Code on Commerce Law (KUHD) and the Book of Code on Private Law (KUH Perdata) equally belongs to the domain of civil law. ${ }^{21}$ The issuance of a letter on the decision to establish a disaster emergency cannot be generalized to the application of the principle of lex specialis derogat lex generalis. The forcing level of a letter of decision issued by an authority of mayor or regent level is not strong enough and is irrelevant to the application of such principle. However, this principle is not applicable without a decree.

In this regard, Jimly Asidiqi designates that the power to determine an emergency status of a disaster should only be at the hand of the president for several arguments.

21 Bagir Manan, Indonesian Positive Law (Yogyakarta: The Faculty of Law Press Indonesian Islamic University, 2004) 56. 
First, the legal implications of the issuance of such decree are very broad; in that, the decree overrides existing laws and grants overwhelming authority to its publisher. However, Jimly's opinion is not compatible with the spirit of local-scale emergency response that requires immediate response..$^{22}$

Second, the determination of a disaster emergency status and the changes it comes up with is such a serious legal issue that it should be directly handled by the president as the highest authority of the state. It will be inappropriate if the determination of a disaster emergency status is associated with decentralization. The head of the state is the only authority to have the right to turn over the legal status from normal to emergency. Changing the legal status of a state or a region from normal to different conditions and revoking it back to its normal status constitute serious legal issues, so it should be made on the basis of legislation.

Third, the domain of law is one of the six affairs that lie under the authority of the central government; Therefore, it is inappropriate for the head of a regional government to override a normally applying law to an abnormal or special one. Such a power should belong to the authority of the head of the state. Jimly exemplifies how it applies in the United States; whereby the authority to establish an emergency status is solely at the hand of the president even though the scale of the disaster was only at the state level.

In reality, if the head of a regional government is not given the authority to determine the emergency status of a disaster, he or she will not have the access and the right to use the readily-available funds and the budgeted unexpected expenditures that are urgently needed to handle the emergency situation. The head of the regional government will be constrained by the bureaucracy that is deliberately created to rule out the matters according to normal law which is intended to provide a legal certainty and clarity to allow manifesting the legal accountability. Quick measures such as the carrying out the evacuation process, distributing the basic needs to victims, and restoring the public

22 Muhammad Yasin, "Jimly Kritik Aturan Penetapan Status Darurat Bencana," accessed April 15, 2019, https://www.hukumonline.com/berita/baca/lt5cb445eeb6f90/jimlykritik-aturan-penetapan-status-darurat-bencana. 
facilities and infrastructure in an emergency, require elegant financial and support resources that call for strict accountability in the Indonesian legal system.

In light of these considerations, the decision to issue a letter on establishing a disaster emergency is appropriately carried out through delegation based on the spirit of decentralization. The letter declares the start of a special legal promulgation within a limited period of time onto an object in a certain region that requires emergency handling. This represents an appropriate way and constitutes a special legal principle that strongly overrides a generally applying law, and the letter of decision comes together with an authority directly granted by the legislation.

What legal implications that will arise upon the issuance of the Disaster Emergency Status Decree? The establishment of a series of phases namely the pre-disaster, disaster emergency and post-disaster periods is intended by the UUPB to provide the legal status for respective stages of the disaster response measures. The activities during the emergency response phase include, making rapid and accurate assessment of the severity of damages and the available resources, determining the emergency status of the disaster, rescuing and evacuating the affected communities, distributing the basic needs, protecting the vulnerable groups, and immediately restoring the vital public infrastructure and facilities (Article 48 of the UUPB). The emergency response is an effort carried out immediately after the disaster to overcome the impact of the disaster. One of the characteristics of an emergency condition is that the situation is chaotic, where speed and accuracy in making decisions and acting is required. Article 50 of UUBA stated:

"In the event that the status of a disaster emergency is determined, the National Disaster Management Agency and the Regional Disaster Management Agency have access facilities."

The facilities referred to include the mobilization of human resources, deployment of equipment, logistics, immigration, customs and quarantine, licensing, procurement of goods or services, management and accountability of money and or goods, rescue and command to order and mobilize sectors or institutions. In these situations, anyone who intentionally inhibits the access to facilities can be punished by imprisonment for a minimum of 3 (three) years or a maximum of 6 (six) years and a fine of at least Rp. 2,000,000,000.00 (two billion 
rupiah) or Rp. 4,000,000,000.00 (four billion rupiahs) at the most (Article 77).

These access facilities are further regulated by Government Regulation No. 21 of 2008 concerning Disaster Management where legal lines are provided that it can be carried out by the Head of the BPBD and Head of BNPB in accordance with their level.

In the field of procurement of goods / services during a disaster emergency, PP 21 of 2018 provides several conditions. Procurement of goods or services must be carried out in a planned manner by taking into account the type and number of needs in accordance with the conditions and characteristics of the disaster in the area and can be carried out specifically through effective and efficient purchasing or direct procurement based on the emergency response conditions. It is not even determined by the amount and price of goods or services such as procurement that exceeds Rp. 200 million must be made through tenders (article 40, PP 21/2008). However, the procurement of goods or services only includes equipment and/or services for search and rescue of disaster affected people, emergency assistance, and the evacuation of the affected community. In addition, the need for clean water and sanitation, food, clothing, health services, shelter and temporary shelter is undeniable.

In the Presidential Regulation of the Republic of Indonesia Number 16 of 2018 concerning Government Goods/Services Procurement in Chapter VIII Part One concerning Special Procurement of Goods/Services Procurement in the Context of Emergency Management, the handling of emergencies is carried out for the protection of the community or Indonesian citizens inside the country and/or within a foreign country whose implementation cannot be postponed and must be carried out immediately (Article 59 (1). The emergency situations include, natural disasters, non-natural disasters, and/or social disasters. This also includes the implementation of search and rescue operations, damage to facilities or infrastructure that can disrupt public service activities during natural disasters, non-natural disasters, social disasters, developments in the political and security situation abroad, and/or the enactment of foreign government policies that have a direct impact on the safety and order of Indonesian citizens abroad and/or provision for humanitarian assistance to other countries affected by the disaster. 
Unlike PP No 21 of 2008 which states that the procurement of goods or services is not included in the object of recovery of infrastructure and facilities and is only intended for handling emergencies. Perpres 16 of 2018 states that the handling of emergencies can be carried out with the use of permanent construction, in terms of handover, permanent construction must be during the emergency period. As for handling permanent construction during emergencies, the completion of the work may be beyond the emergency period. (Article 59). ${ }^{23}$

\section{The utilization of Ready-to-Use Funds}

Allocation of disaster management budget in the form of ready-to-use funds has been mentioned in article 6, letter of the UUPB. During an emergency response, BNPB uses ready-to-use funds (Article 62 (1)). The ready-to-use funds are provided by the Government in the BNPB budget, for the procurement of goods and/or services during disaster response. The BPBD uses the funds that can be provided in the APBD and placed in the BPBD budget for the procurement of goods and / or services during disaster response. (Article 41). PP No. 22/2008 concerning Disaster Management Fund defines that the ready-to-use Funds as funds that are always available and reserved by the Government to be used during disaster emergency response until the expiry date of the emergency (Article 1). Local governments can provide ready-made funds in the disaster management budget originating from the APBD, stored in the BPBD budget, as stated in (Article 6 PP 22/2018). The use of ready-made funds is limited to the procurement of goods and/or services for the search and rescue of disaster victims, emergency help, evacuation of disaster victims, clean water and sanitation needs, food clothing, health services and temporary shelter.

\section{Unexpected Expenses}

The subject of Unexpected Expenditures is regulated in the Government Regulation Number 58 of 2005 concerning Regional

23 Presidential Regulation 16 of 2018 , article. 59, section. 2. 
Financial Management. According to the PP, an emergency must at least meet the following criteria:

1. it is not a normal activity of local government activities and cannot be predicted beforehand,

2. it is not expected to occur repeatedly,

3. it is beyond the control and influence of the local government, and

4. it has a significant impact on the budget in the context of recovery caused by an emergency. ${ }^{24}$

The implementation of expenditures on emergency funding and/or extraordinary circumstances, it is specifically determined by regional head regulations. ${ }^{25}$ In an emergency, the local government can make expenditures that are not yet available in the budget, which are then proposed in the amended draft to the Regional Budget ${ }^{26}$.

Emergency funding is formulated first in the Regional Work Unit Budget Work Plan (RKA-SKPD), except for disaster emergency response needs. ${ }^{27}$ Thus, for disaster emergency response needs, the funding does not require prior formulation in the RKA-SKPD. Expenditures for emergency response needs are immediately charged on unexpected expenditure. ${ }^{28}$ Expenditures for disaster emergency response are used only for related needs such as the search and rescue of disaster victims, emergency relief, evacuation of disaster victims, clean water and sanitation needs, food, clothing, health services and shelter. ${ }^{29}$

24 Government Regulation, Number 58 of 2005, article. 83, 1.

25 Ibid, 3.

26 Decree of the Minister of Home Affairs Number 13 of 2006 concerning Guidelines for Regional Financial Management, as amended several times and then last time amended by Minister of Home Affairs Regulation Number 21 of 2011 concerning Second Amendment to Minister of Home Affairs Regulation Number 13 of 2006 concerning Guidelines for Regional Financial Management, article. 162. Ibid, 8.

28 Ibid, 8a.

29 Ibid, 8 b. 


\section{Legal Implications of Disaster Emergency Status}

What has the central government do to cover up the absence of law in this field? First, BNPB has published BNPB decree Number 14 of 2010 concerning Guidelines for Establishing a Disaster Emergency Response Command Post in which there are several technical instructions on how to establish Command Posts which are associated with emergency status. However, this decree does not specifically regulate the legal mechanism for determining disaster emergency status and disaster level.

Second, BNPB only published a Disaster Emergency Determination Handbook 10 years after the disaster emergency happened, which cannot be categorized as a legal document because the book is only a technical guideline that has not been well socialized. For this reason, when the implementation of disaster emergency status is examined, it cannot be used as a legal reference, as it can only be considered as a policy regulation (beleidsregels), a form of "regulation" in addition to legislation contained in the practice of daily governance. $^{30}$

Article 22A of the 1945 Indonesian Constitution is outlined in Law Number 10 of 2004 concerning the Establishment of Legislation which regulates organic law. The legal actions or actions of the government must be based on the prevailing laws and regulations in Indonesia which are divided into Regulations that are included in the type and hierarchy of laws and regulations, which consist of Constitution, Law, Government Regulations Substituting Laws, Government Regulations, Presidential Regulations, and Regional Regulations (Article 7 paragraph (1) and other types of regulations which are recognized and have the binding powers as long as they are ordered by higher laws and regulations (Article 7 paragraph (4) and its explanation). The types of regulations referred to are Regulations issued by the People's Consultative Assembly (MPR), House of Representatives (DPR), Regional House of Representatives (DPRD), Supreme Court (MA), Constitutional Court (MK), the audit board of the republic of Indonesia (BPK), Bank Indonesia, Ministers, heads of

30 Drs. Zafrullah Salim, S.H, "Artikel Hukum Tata Negara dan Peraturan Perundang-undangan,” accessed May 10, 2011, http://ditjenpp.kemenkumham.go.id.htn-dan-puu/1299-legislasi-semupseudowetgeving.html. 
government agencies, institutions or commissions of the same level established by law or the government at the behest of legislation, Provincial DPRD, governor, Regency / City DPRD, Regent / Mayor, and Village Head or equivalent.

The unification of the system is based on the fact that lower norms are determined by other higher norms. ${ }^{31}$ To overcome this problem, the government must first issue a Presidential Regulation concerning the determination of emergency status and the level of disasters. In PP, there are at least some basic issues that must be regulated, for example legal mechanism on how a decree regarding the emergency status of a disaster can be issued, both national status and provincial or district level, then defining the size of the benchmark of the indicators set out in the UUPB so that each responsibility of each level of the disaster becomes clear. Then setting the time period so that the determination of disaster emergency status is for the benefit of handling the immediate situation, including security issues, the purpose of which a disaster emergency determination is limited.

Secondly, local governments that already have Regional Regulations can immediately conduct a review of Disaster Management that can include a legal mechanism regarding the determination of disaster emergency status, along with the indicators.

Third, at the initiative of the DPD-RI, academic texts can also be prepared for review of the UUPB. There are several things that can be reviewed, namely the definition of disaster, the separation of the phases of disaster emergency status with the level of the disaster, strengthening the position of the BNPB / BPBD, and the obligation to allocate the budget.

\section{CONCLUSION}

A rule that contains the law must be a positive law that is based on, and in accordance with facts that are formulated into a law that is not easily changed. The absence of the law on determining the status of an

31 Sulaiman Tripa \& Danil Akbar Taqwadin, "Legislation Policy in Relation to Disaster Mitigation in Aceh, the Aceh Legal Study Institute/LKHA," Journal of Disaster Management 1, no 4 (2013): 4. 
emergency is issued under the Presidential Regulation, has provided legal uncertainty on the ground.

The status of an emergency decision is issued broadly, such as by only a decree that can override normal law or there are special laws that require more funds for procurement of goods, increase authority in accessing, supporting, sending human resources and equipment, supporting financial accountability, use of state facilities, use of state funds either through BTT, DSP and RR Funds. A formal and autonomous law should be introduced, but the greatest authority granted by law to regional heads and presidents cannot be balanced with implementing rules needed to make decisions relating to legal matters only to use easy access, arbitrary state finances.

The absence of the Perpres requires a form of law in the determination of the emergency for a disaster, but the regional head continues to issue the decree of the stipulation by their own. Hence it would need a serious discussion on how such regulation in determining the status of emergency can be initiated, in order to guide the regional government facing any kind of disasters without leading to arbitrary power in using the national budget. The suspicion of corruption when determining such emergency status has become a concern of Indonesian people. Hence, it is a time for more transparency and accountability on the part of those in power when determining a state of emergency during a disaster in Indonesia. 